\title{
Impact of wood fraction, moisture and steam explosion on the development of an innovative insulation material
}

\author{
Martins Andzs, Ramunas Tupciauskas, Andris Veveris, Janis Gravitis \\ Latvian State Institute of Wood Chemistry, Laboratory of Eco-Efficient Conversion of Biomass1, \\ Dzerbenes street 27, Riga, LV-1006, Latvia.
}

\begin{abstract}
The study shows development of an innovative bulk heat insulation material from grey alder (Alnus incana L. Moench) chips and birch (Betula pendula, Betula verrucosa) flakes as residues of plywood production. The research is actual for the plywood production companies and for producers that process grey alder chips to make an innovative products with high added value. Chips and flakes eco-efficient converted to fibrous mass by steam explosion (SE) technology at temperatures (T) of 200 to $235{ }^{\circ} \mathrm{C}$ and time interval of 0 to $5 \mathrm{~min}$. Application of SE technology to obtain fibrous insulating material is in the news at a global level and has not been studied previously. The bulk density of raw and SE materials determined using standardised method specified in LVS EN 15103: 2010. The bulk density of SE materials studied depending on the raw material fraction and moisture as well as depending on the SE conditions. The lowest bulk density $\left(53 \mathrm{~kg} \mathrm{~m}^{-3}\right)$ achieved SE material of grey alder chips with $12 \%$ of raw moisture processed at $\mathrm{T} 235{ }^{\circ} \mathrm{C}$ for $1 \mathrm{~min}$. This is the optimal result, which reveals the industrial competitiveness of bulk heat insulation materials and indicate the justification for the further examination.
\end{abstract}

Keywords: grey alder, birch flakes, steam explosion, bulk density, bulk heat insulation.

\section{INTRODUCTION}

Alder as the fourth most Latvian widespread tree species is still not used in sufficient quantities. In forests, near the pine and spruce basic wood species, grows huge resource of grey alder that count of 40 million cubic meters $\left(\mathrm{m}^{-3}\right)$ or $6.1 \%$ of the total Latvian forest yield [1] Therefore, grey alder species retains the potential for use in materials with high added value. By contrast, the production of plywood forms a considerable amount of so-called veneer flaps which are predominantly burned for energy purposes [2]. Currently, Latvia implements „Technology platform vision 2030 of Latvian forestry and forestbased industry", which one of the objectives is the innovative development and application increase of Latvian major tree species and wood products [3]. In response to the technological platform the research of the above-mentioned raw materials is sustainable based.

Traditionally, to convert wood chips to pulp, defibrators and rafinators are used. In nowadays, steam explosion (SE) pretreatment is one of the most promising technologies for biomass processing [4].

$\mathrm{SE}$ is the thermal hydrolysis process by which saturated steam acts on the biomass in a closed reactor a certain time (up to $10 \mathrm{~min}$ ) at a certain temperature $\left(160-250{ }^{\circ} \mathrm{C}\right)$. After the time exceeds the reactor is opened and the biomass is exploded to the receiver due to rapid pressure reduction. Wood fibres after SE are a modified hierarchical assembly of its main ingredients - cellulose, hemicellulose and lignin (Fig. 1).

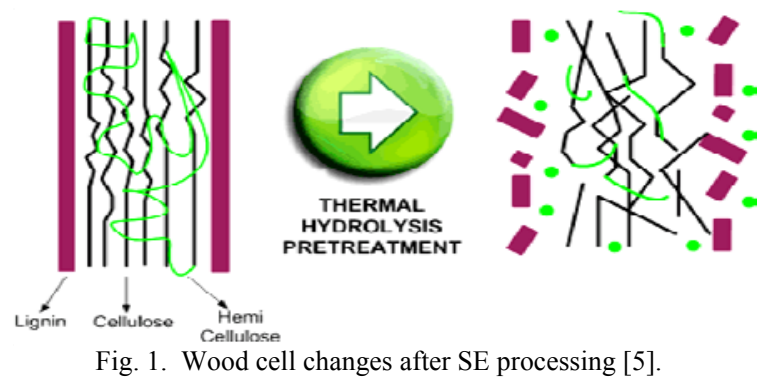

During the research is intended to develop the optimal bulk heat insulation material from grey alder wood chips and veneer flaps, with the use in building structures. The article shows the study, the purpose of which is to provide the impact of raw material fraction, moisture and SE treatment on the bulk density of the pretreated material. The tasks of the study are to develop and implement a sample treatment scheme by selecting the sample different 
fraction, moisture and SE modes, as well as to determine the sample optimal (lower) bulk density.

\section{MATERIALS AND METHODS}

To implement targets of the research the processing scheme has been developed (Fig. 2). Grey alder wood is obtained from the sample squares of Latvian State Forestry Research Institute „Silava”. Birch flaps is obtained from the plywood production company's "Latvijas Finieris". The grey alder wood is crashed by a "Bruks" (Sweden) wood chipping machine, debarked and then one part cracked by a "Retsch" (Germany) appliance to particles (AP) characterised by sieve holes of $10 \mathrm{~mm}$ in diameter. The grey alder chips (AC) and birch flaps (BF) fractionated by sieve with holes of $20 \mathrm{~mm}$ in diameter. Finally, all raw materials conditioned to equilibrium moisture content (MC) that was achieved $6 \pm 1 \%$ after one week and to $12 \%$ of MC. The MC of raw materials controlled using the device Precisa XM120.

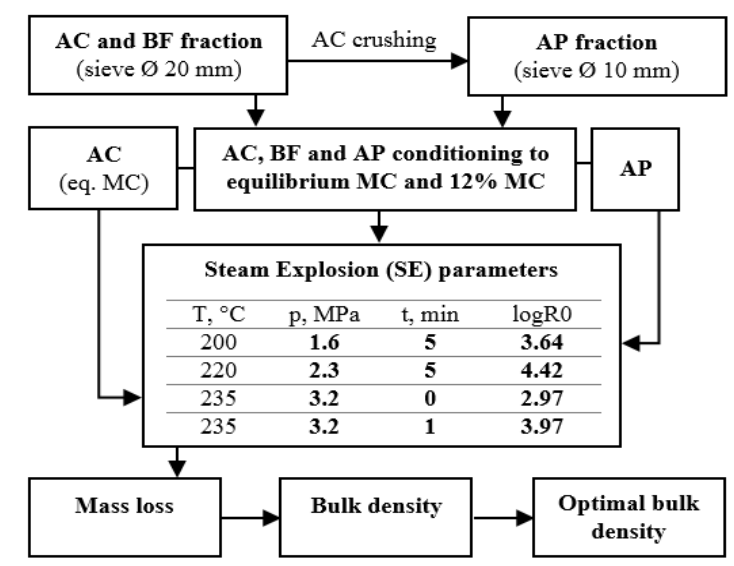

Fig. 2. Research scheme of grey alder chips (AC), particles (AP) and birch flaps (BF).
The bulk density (Dar, $\mathrm{kg} \mathrm{m}^{-3}$ ) of conditioned raw materials determined using a standardized method [3] at cylindrical metal container of 0.5 litres $\left(\mathrm{V}, \mathrm{m}^{3}\right)$ and calculated by equation (1):

$$
D_{a r}=\frac{\left(m_{2}-m_{1}\right)}{V},
$$

where $\mathrm{m}_{1}$ - the mass of the empty container in $\mathrm{kg}$; $\mathrm{m}_{2}$ - the mass of the sample filled container in $\mathrm{kg}$.

Prepared raw materials processed in the laboratory scale batch SE unit (Fig. 3), which allows to change the processing parameters: time, temperature and pressure. Empirically, conditions of the SE can be characterised by a single treatment severity index $\left(\mathrm{R}_{0}\right)$ comprising temperature $(\mathrm{T})$ and time $(\mathrm{t})$ [7]:

$$
R_{0}=t \cdot \exp \frac{(T-100)}{14.75}
$$

The same pretreatment quality could be achieved combining the process temperature and time [6]. Therefore, the temperature range was choose from $200^{\circ} \mathrm{C}$ to $235^{\circ} \mathrm{C}$ and time of exposure to high pressure at current temperature from $0 \mathrm{~min}$ to $5 \mathrm{~min}$. The time of 0 min there means that the sample was exploded to receiver immediately after the current pressure was achieved.

SE pretreatment parameters for used raw samples are shown in Table 1. In order to reduce the number of samples, the AP samples with MC of equilibrium and $12 \%$ processed with single SE mode at T $200{ }^{\circ} \mathrm{C}$, t 5 min (Fig. 2, Table 1). While one of AC samples with only equilibrium MC processed with single SE mode at $\mathrm{T} 235{ }^{\circ} \mathrm{C}$ and steam-exploded immediately after the high pressure achieved (Fig. 2, Table 1).

TABLE 1

SE TREATMENT PARAMETERS OF RAW SAMPLES

\begin{tabular}{|l|c|c|c|c|c|c|}
\hline Sample & $\begin{array}{c}\text { Fraction } \\
\text { (sieve Ø, mm) }\end{array}$ & $\begin{array}{c}\text { MC } \\
\text { (before SE) }\end{array}$ & T, ${ }^{\mathbf{C}}$ & p, Mpa & t, min & $\mathbf{l o g R}_{\mathbf{0}}$ \\
\hline BF_W12_R3.97 & 20 & 12 & 235 & 3.2 & 1 & 3.97 \\
\hline BF_W5_R3.97 & 20 & 5 & 235 & 3.2 & 1 & 3.97 \\
\hline BF_W12_R4.23 & 20 & 12 & 220 & 2.3 & 5 & 4.23 \\
\hline BF_W5_R4.23 & 20 & 5 & 220 & 2,3 & 5 & 4.23 \\
\hline BF_W5_R3.64 & 20 & 5 & 200 & 1.6 & 5 & 3.64 \\
\hline AC_W7_R2.97 & 20 & 7 & 235 & 3.2 & 0 & 2.97 \\
\hline AC_W12_R3.97 & 20 & 12 & 235 & 3.2 & 1 & 3.97 \\
\hline AC_W6_R3.97 & 20 & 6 & 235 & 3.2 & 1 & 3.97 \\
\hline AC_W12_R4.23 & 20 & 12 & 220 & 2.3 & 5 & 4.23 \\
\hline AC_W6_R4.23 & 20 & 6 & 220 & 2.3 & 5 & 4.23 \\
\hline AC_W12_R3.64 & 20 & 12 & 200 & 1.6 & 5 & 3.64 \\
\hline AC_W6_R3.64 & 20 & 6 & 200 & 1.6 & 5 & 3.64 \\
\hline AP_W7_R3.64 & 10 & 6 & 200 & 1.6 & 5 & 3.64 \\
\hline AP_W12_R3.64 & 10 & 12 & 200 & 1.6 & 5 & 3.64 \\
\hline
\end{tabular}




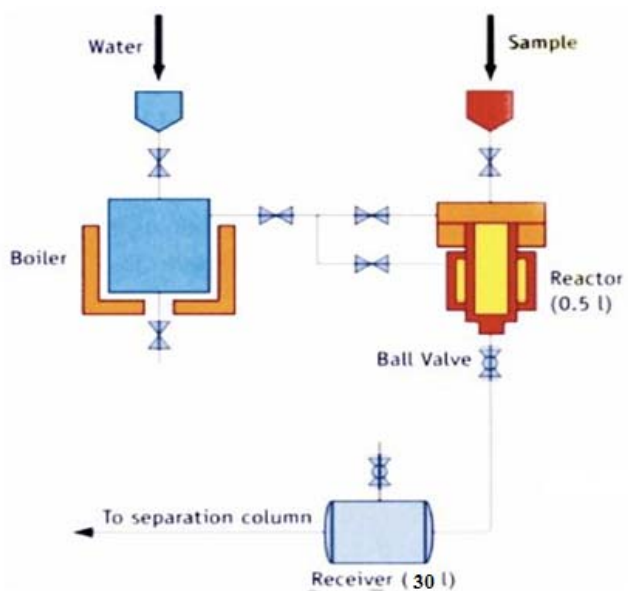

Fig. 3. Scheme of the laboratory scale SE device.

In order to assess the impact of SE regimes used the pretreated materials were collected and it's oven dry mass calculated. Mass loss $\left(\mathrm{M}_{\text {loss }}\right)$ of the $\mathrm{SE}$ materials calculated according to equation (3):

$$
M_{\text {loss }}=100-\frac{\left(m_{2} \times 100\right)}{m_{1}},
$$

where $\mathrm{m}_{1}$ and $\mathrm{m}_{2}-$ is the oven dry mass of raw sample and pretreated one, respectively.

The influence of samples factors and comparison of it's the mean values are analysed by one-way ANOVA at the confidence level $\alpha=0.05$.

\section{RESULTS AND DISCUSSION}

As it is known a certain part of biomass volatiles out during SE. This part is defined as mass loss and contains degraded hemicelluloses $[6,8]$. Mass loss of pretreated samples mostly depends on severity of the SE process and it indicates tight correlation approving the statement that increasing the severity index R0 by one unit the mass loss increases by almost $9 \%$ (Fig. 4). The mass loss variation at $\log \mathrm{R}_{0}$ 3.64, 3.97 and 4.27 depends on moisture content of the raw materials and slightly decreases with the increasing moisture content from $6 \%$ to $11 \%$ (Tupciauskas et al. 2012). The last statement matches also the studies of other authors those declare that the optimal moisture is within range of $10-15 \%$ [9]. While fraction and species of the raw materials show no significant impact on the mass loss.

The bulk density of all raw materials varies in range between 154 and $172 \mathrm{~kg} \mathrm{~m}^{-3}$ and the difference is not significant in spite of different fraction, moisture and species (Fig. 5).

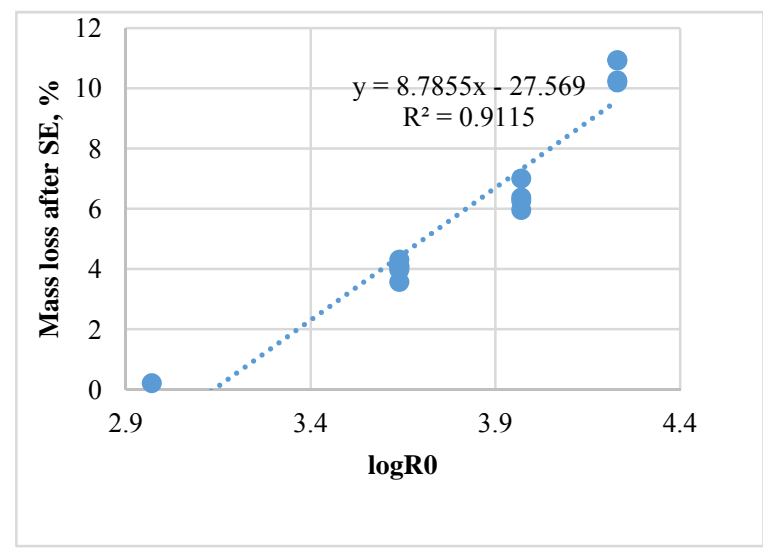

Fig. 4. Mass loss of the samples after SE depending on severity index $(\log R 0)$

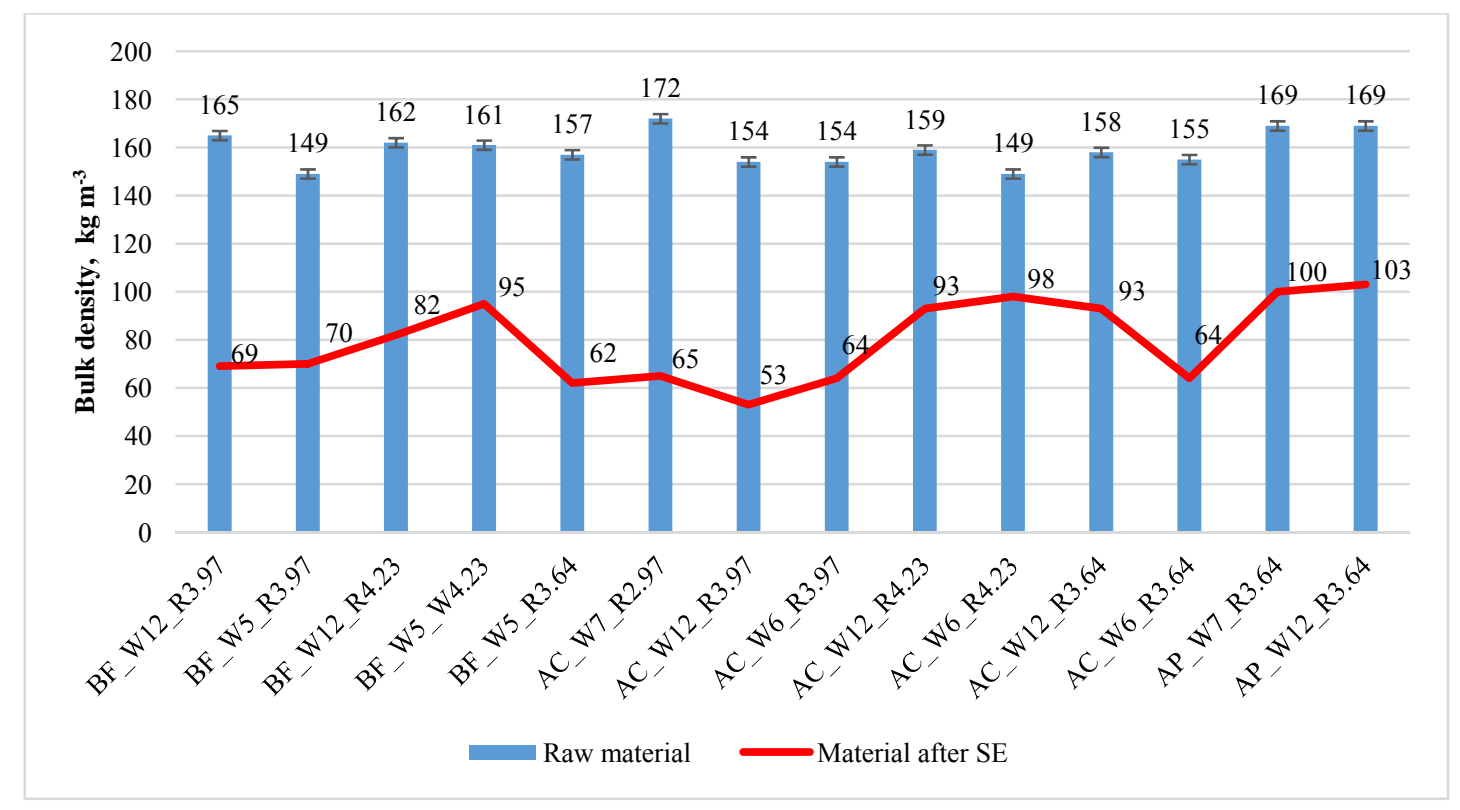

Fig. 5. Bulk density of all samples before and after the processing of SE. 


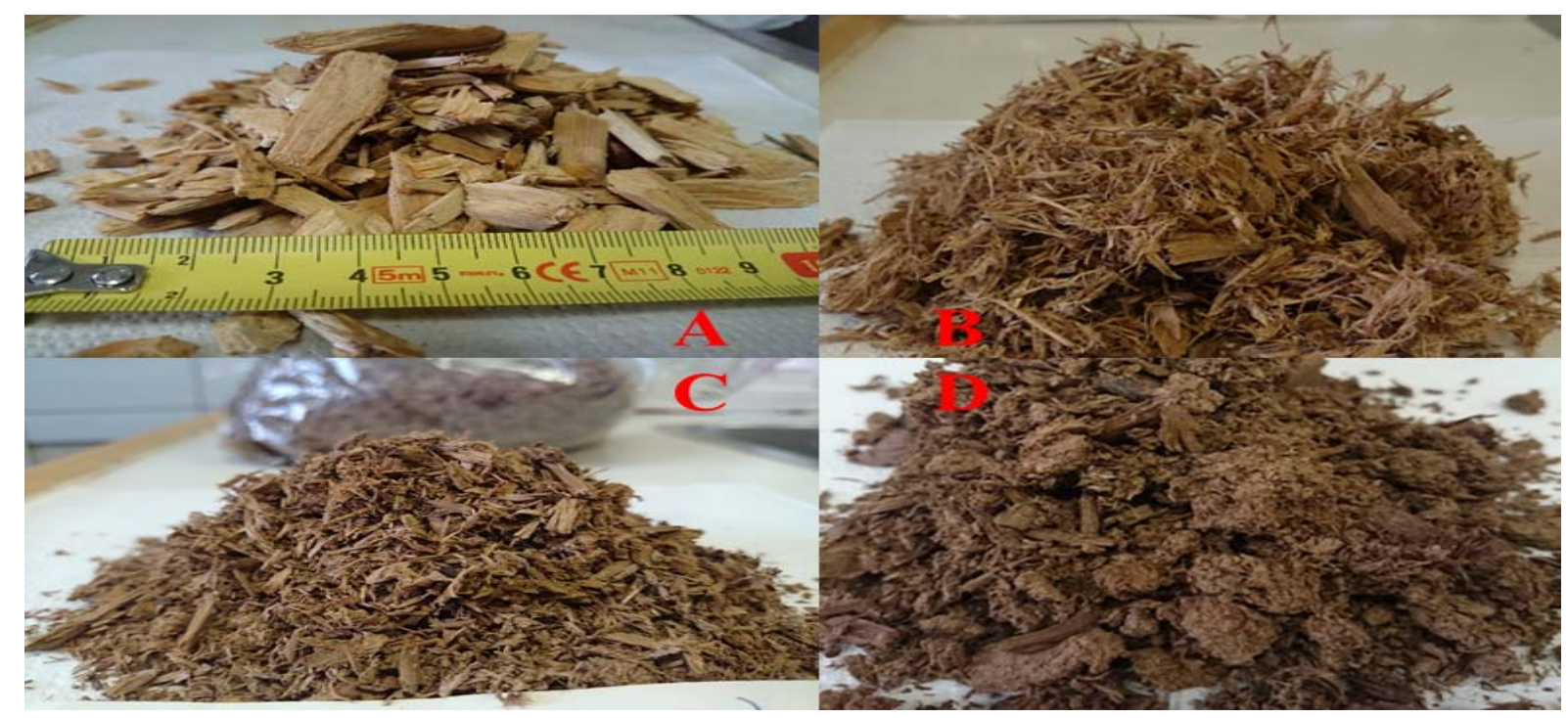

Fig. 6. Visual appearance of the bulk samples: A - raw AC, B - AC_W7_R2.97; C-AP_W12_R3.64; D - AC_W12_R4.23.

The bulk density of the pretreated materials variate in range between 62 and $103 \mathrm{~kg} \mathrm{~m}^{-3}$. The bulk density of all raw materials varies in range between 154 and $172 \mathrm{~kg} \mathrm{~m}^{-3}$ and the difference is not significant as in the case of raw materials (Fig. 5). The lowest bulk density achieved by sample from raw alder chips pretreated at $\mathrm{T} 235^{\circ} \mathrm{C}$ and $1 \mathrm{~min}$, however the samples from birch flaps also demonstrate good enough results (Fig. 5). The pretreated samples of raw grey alder particles achieved higher bulk density indicating unsatisfactory results. The bulk density of the pretreated samples have a tendency to increase with increasing severity index as also noted by Tupciauskas et al. [10].

The bulk density of the pretreated materials decreased in average at $50 \%$ due to the effect of SE. However, the pretreated materials are not homogenous because of including single fibres and fibre bundles as well (Fig. 6).

\section{CONCLUSION}

Processing of grey alder chips and birch flaps there are obtained inhomogeneous fibrous mass that consist of fibres and fibre bundles.

SE optimal conditions under which the samples obtained with the lowest bulk density are $\mathrm{T} 235^{\circ} \mathrm{C}, \mathrm{p}$ $3.2 \mathrm{MPa}$ and $\mathrm{t} 0-1 \mathrm{~min}$.

In spite of different parameters some samples pretreated under $\operatorname{logR0} 4$ (PF_W5_R3.64, AC_W7_R2.97, AC_W12_R3.97, AC_W6_R3.97, AC_W6_R3.64) achieved optimum bulk density (under $\overline{65} \mathrm{~kg} \mathrm{~m}^{-3}$ ) that is comparable with other bulk heat insulation analogues. This is the optimal result, which reveals the industrial competitiveness of bulk heat insulation materials and indicate the justification for the further examination.

\section{ACKNOWLEDGMENTS}

The studies were implemented under the National Research Programme at Latvian State Institute of wood chemistry, Project No. 3. "Biomaterials and Bioproducts with extensive use of forest resources" $2014-2017$.

\section{REFERENCES}

[1] Latvian Central Statistical Bureau, January 2015 [Online] Available: http://www.csb.gov.lv/dati/koku-sugas-latvijasmezos-30236.html [Accessed: January 15. 2015]

[2] Latvian State Environmental Service B permit environmental pollution. SIA VEREMS RSEZ file: April 2012 [Online] ///C:/Users/User/Downloads/b-rsez-veremsre12ib0006\%20(1).pdf [Accessed: January 15. 2015]

[3] Latvian Academy of science "Home page" March 2006. [Online] Available: http://www.lza.lv/ZV/zv062000.htm\#6 [Accessed: March 20. 2015]

[4] Wolfgang Stelte, Danish Technolgy institute, Report SE method, Available: file://C:/Users/User/Downloads/RK\%20 report\%20steam \%20explosion.pdf [Acessed January 16.2015]

[5] March 2006. [Online] Available http://www.hrsheatexchangers.com/en/applications/biofuels/bioethanol/defau lt.aspx [Acessed January16.2015]

[6] Гравитис, Я. А. 1987. Теоретические и прикладные аспекты метода взрывного автогидролиза растительной биомассы. Абзор. Химия древесины, 5:3 - 21 .

[7] Overend, R.P., Chornet, E. Fractionation of Lignocellulosics by steam aqueous pretreatments. Philos. Trans. R. Soc. Lond. Ser. A-Math. Phys. Eng. Sci., 1987. 321(1561):523-536.

[8] Веверис, А. Г., Эринш, П. П., Калейне, Д. А., Полманис, А.Г., Веверис, Г.П, Кузмане, Г.В. 1990. Высокотемпературный автогидролиз древесины. 1. Сопоставление поведения древесины основных пород Латвийской ССР. Химия древесины, 3: 89-95.

[9] Abolins, J., Gravitis, J. 2007. Biomass conversion to transportation fuels, combustibles and nano-materials by steam explosion. Latvian J. Phys. Techn. Sci., 4: 29 - 39. 
Martins Andzs, et al./ Environment. Technology. Resources, (2015), Volume I, 11-15

[10] Tupciauskas, R., Veveris, A., Belkova, L., Gravitis, J. and Tuherm, H. 2012. Grey alder pretreatment by steam explosion for self adhesive composites. In: A. Baltrušaitis and $\mathrm{K}$. Ukvalbergiene (eds.) Proceedings of the $8^{\text {th }}$ Meeting of the
Northern European Network for Wood Science and Engineering (WSE), 13-14 September, Kaunas, Lithuania. Kaunas University of Technology: Technologija, 214-220. 